\title{
HUBUNGAN ANTARA PARTUS LAMA DENGAN KEJADIAN PERDARAHAN POSTPARTUM DINI DI KAMAR BERSALIN RUMAH SAKIT UMUM Dr. SAIFUL ANWAR MALANG
}

\author{
Siti Candra Windu Baktiyani` ${ }^{\star 凶}$, Rahmaniar Meirani** Uswatun Khasanah ${ }^{\star *}$
}

\begin{abstract}
Abstrak
Persalinan yang tidak ditangani dengan baik dapat menyebabkan proses persalinan tidak berjalan lancar dan persalinan berlangsung lebih lama atau terjadi partus lama. Partus lama dapat menyebabkan perdarahan postpartum dini, yang merupakan penyebab terpenting kematian maternal di Indonesia. Penelitian ini bertujuan untuk mengetahui hubungan antara partus lama dengan kejadian perdarahan postpartum dini. Metode penelitian yang digunakan adalah observasional analitik dengan desain cross sectional yang dilakukan terhadap ibu yang bersalin pervaginam di kamar bersalin Rumah Sakit Umum Dr. Saiful Anwar Malang pada tanggal 11 Juni-11 September 2012. Variabel yang diukur adalah partus lama dan kejadian perdarahan postpartum dini. Dari hasil penelitian didapatkan 25 ibu mengalami partus lama dan 35 ibu tidak mengalami partus lama. Ibu yang mengalami partus lama lebih banyak yang mengalami perdarahan postpartum dini $(72 \%)$ dibandingkan yang tidak mengalami partus lama $(34,29 \%)$. Analisis data dengan menggunakan chi square menunjukkann nilai $x^{2}$ hitung $>x^{2}$ tabel $(8,287>6,64)$ dan $p=0,004<0,01$ yang menunjukkan ada hubungan yang signifikan antara partus lama dengan kejadian perdarahan postpartum dini. Besarnya hubungan tersebut adalah 0,349 (rendah), yang menunjukkan bahwa partus lama hanya mempengaruhi kejadian perdarahan postpartum dini sebesar $12,18 \%$, sedangkan sisanya yakni $87,82 \%$ di pengaruhi oleh faktor lain. Kesimpulan penelitian ini yaitu semakin lama proses persalinan maka kemungkinan untuk terjadinya perdarahan postpartum dini semakin besar.
\end{abstract}

Kata kunci : partus lama, perdarahan postpartum dini.

\section{RELATIONSHIP BETWEEN PROLONGED LABOR AND EARLY POSTPARTUM HAEMORRHAGE AT DELIVERY ROOM OF PUBLIC HOSPITAL Dr. SAIFUL ANWAR MALANG}

\begin{abstract}
Labor which is not handled well can cause non-current labor and it is longer than normal or called prolonged labor. Prolonged labor can cause early postpartum haemorrhage, the most important cause of maternal mortality in Indonesia. This study was aimed to know relationship between prolonged labor and early postpartum haemorrhage. Method used in this reseach is analytic observational with crosssectional design toward mothers with vaginal delivery at delivery room of Public Hospital Dr. Saiful Anwar Malang during June $11^{\text {th }}$-September $11^{\text {th }}, 2012$. Variables measured are prolonged labor and early postpartum haemorrhage. Results showed that 25 mothers had prolonged labor and 35 mothers have had not prolonged labor. Mothers who have prolonged labor would experience early postpartum haemorrhage $(72 \%)$ more than those who did not have prolonged labor $(34.29 \%)$. Chi square analysis revealed that $x^{2}$ calculated $>x^{2}$ table $(8.287>6.64)$ and $p=0.004<0.01$, it is mean that there was significant relationship between prolonged labor and early postpartum haemorrhage. The relationship was 0.349 (low), which showed that prolonged labor would only affect early postpartum haemorrhage for $12.18 \%$ while the remain $87.82 \%$ was affected by other factors. To conclude, this study was indicated that the longer duration of labor, the bigger possibility of early postpartum haemorrhage.
\end{abstract}

Keywords: early postpartum haemorrhage, prolonged labor.

* Lab Obstetri dan Ginekologi, RSSA-FKUB

** Program Studi Kebidanan, FKUB

${ }^{凶}$ E-mail: siticandrawb@gmail.com 


\section{Pendahuluan}

Persalinan normal adalah proses pengeluaran janin yang terjadi pada kehamilan cukup bulan (37-42 minggu), lahir spontan dengan presentasi belakang kepala yang berlangsung dalam 18 jam, tanpa komplikasi baik pada ibu maupun pada janin. Namun demikian, terkadang persalinan tidak ditangani dengan baik sehingga dapat menyebabkan proses persalinan tidak berjalan lancar sehingga lama persalinan lebih lama dari normal atau terjadi partus lama. Partus Lama merupakan salah satu dari beberapa penyebab kematian ibu dan bayi baru lahir. 1,2

Menurut Wahyuningsih (2010), partus lama adalah persalinan yang berlangsung lebih dari 18 jam yang dimulai dari tandatanda persalinan. Insidensi partus lama bervariasi dari 1 hingga 7\%. Partus lama rata-rata di dunia menyebabkan kematian ibu sebesar $8 \%$ dan di Indonesia sebesar $9 \%{ }^{2}$ Pada tahun 2011, dari 1864 persalinan pervaginam di Rumah Sakit Umum dr. Saiful Anwar Malang didapatkan partus lama sebanyak 455 persalinan.

Partus lama akan menyebabkan infeksi, kehabisan tenaga, dehidrasi pada ibu. Pada partus lama juga dapat terjadi perdarahan postpartum yang dapat menyebabkan kematian ibu. Pada janin akan terjadi infeksi, cedera dan asfiksia yang dapat meningkatkan kematian bayi. $^{2}$ Partus lama juga menyebabkan perdarahan postpartum, yang merupakan penyebab terpenting kematian maternal di Indonesia.

Penyebab kematian maternal di Indonesia adalah perdarahan $40-60 \%$, infeksi $20-30 \%$ dan keracunan kehamilan $20-30 \%$, sisanya sekitar $5 \%$ disebabkan penyakit lain yang memburuk saat kehamilan atau persalinan. ${ }^{3}$ Sedangkan di berbagai negara, paling sedikit seperempat dari seluruh kematian ibu disebabkan oleh perdarahan. Proporsinya berkisar antara kurang dari $10 \%$ sampai hampir $60 \% .{ }^{4}$ Di Rumah Sakit Umum Dr. Saiful Anwar Malang pada tahun 2011, dari 1864 persalinan didapatkan 96 persalinan dengan perdarahan postpartum dini. Perdarahan postpartum dini tersebut sebagian besar didahului dengan partus lama.

Pada penelitian ini ingin diketahui hubungan antara partus lama dengan kejadian perdarahan postpartum dini di Kamar Bersalin Rumah Sakit Umum Dr. Saiful Anwar Malang.

\section{Bahan dan Metode}

\section{Desain Penelitian}

Penelitian ini merupakan observasional analitik dengan desain cross sectional. Sampel dalam penelitian ini yaitu ibu bersalin yang partus lama dan mengalami perdarahan postpartum dini di kamar bersalin Rumah Sakit Umum Dr. Saiful Anwar Malang pada tanggal 11 Juni-11 September 2012 yang memenuhi kriteria inklusi yaitu Ibu inpartu kala I fase aktif dan kala II dengan partus lama, Ibu postpartum yang mengalami perdarahan postpartum dini dan kriteria eksklusi sampel yaitu jumlah dan waktu perdarahan yang tidak terkaji, lama persalinan yang tidak terkaji, persalinan dengan tindakan, persalinan yang cepat (presipitatus), ibu dengan penyakit kelainan pembekuan darah dan anemia, ibu inpartu kala I fase laten, ibu dengan sisa plasenta dan laserasi jalan lahir

\section{Prosedur Penelitian}

Peneliti mengamati setiap ibu inpartu fase aktif hingga ibu melahirkan bayi secara keseluruhan. Kemudian mengamati dan mencatat lama persalinan ibu tersebut. Selanjutnya dilakukan observasi terhadap jumlah dan waktu perdarahan yang dialami ibu apakah ibu mengalami perdarah postpartum dini atau tidak. Semua data yang terkumpul dicatat pada lembar partograf, selanjutnya dilakukan analisis data.

\section{Analisis Data}

Data yang didapatkan dari hasil observasi terhadap lama persalinan yang dapat menimbulkan perdarahan postpartum dini dianalisis dengan menggunakan teknik analisis data Chi kuadrat dengan program SPSS 
Hasil

\section{Partus Lama}

Partus lama dibagi menjadi dua kategori yaitu partus lama dan bukan partus lama. Untuk mengetahui kategori partus lama menggunakan lembar observasi berupa partograf. Pada Tabel 1 ditampilkan frekuensi dan persentase responden yang mengalami partus lama dan bukan partus lama dari total responden yang berjumlah 60 orang.

Tabel 1. Frekuensi kejadian partus lama

\begin{tabular}{l|c|c}
\hline \multicolumn{1}{c|}{ Partus lama } & Frekuensi & Persentase \\
\hline Ya & 25 & 41,7 \\
\hline Tidak & 35 & 58,3 \\
\hline Total & 60 & 100 \\
\hline
\end{tabular}

Partus lama diklasifikasikan menjadi 2 yaitu fase aktif memanjang dan kala II memanjang. Ibu yang mengalami fase aktif memanjang sebanyak 19 ibu dengan persentase $76 \%$, sedangkan ibu yang mengalami kala II memanjang sebanyak 6 ibu dengan persentase $24 \%$. Ibu yang mengalami fase aktif memanjang terdiri dari 3 ibu primipara dan 16 ibu multipara, sedangkan ibu yang mengalami kala II memanjang terdiri dari 4 ibu primipara dan 2 ibu multipara.

\section{Perdarahan Postpartum Dini}

Kejadian perdarahan postpartum dini dibedakan menjadi dua kategori yaitu perdarahan postpartum dini dan bukan perdarahan postpartum dini. Pada Tabel 2 ditampilkan frekuensi dan persentase responden yang mengalami perdarahan postpartum dini dan bukan perdarahan postpartum dini dari total responden yang berjumlah 60 orang.

Tabel 2. Frekuensi kejadian perdarahan postpartum dini

\begin{tabular}{l|c|c}
\hline Kejadian perdarahan postpartum dini & Frekuensi & Persentase \\
\hline Tidak & 30 & 50 \\
\hline Ya & 30 & 50 \\
\hline Total & 60 & 100 \\
\hline
\end{tabular}

Penyebab terbanyak perdarahan postpartum dini pada penelitian ini yaitu atonia uteri. Sebanyak 21 ibu yang mengalami perdarahan postpartum dini disebabkan karena atonia uteri sedangkan sisanya yaitu 9 ibu disebabkan karena retensio plasenta.

\section{Hubungan Partus Lama dengan Kejadian Perdarahan Postpartum Dini}

Pada Tabel 3 ditampilkan hubungan partus lama dengan kejadian perdarahan post partum dini berdasarkan hasil tabulasi silang dan uji chi square.

Tabel 3. Tabulasi silang partus lama dengan kejadian perdarahan postpartum dini

\begin{tabular}{l|c|c|c}
\hline \multirow{2}{*}{ Partus lama } & \multicolumn{2}{|c|}{ kejadian perdarahan post partum dini } & \multirow{2}{*}{ Total } \\
\cline { 2 - 3 } & Ya & Tidak & \\
\hline Ya & 18 & 7 & 25 \\
\hline Tidak & 12 & 23 & 35 \\
\hline Total & 30 & 30 & 60 \\
\hline
\end{tabular}

Berdasarkan Tabel 3 diketahui bahwa pada ibu partus lama lebih banyak yang mengalami perdarahan postpartum dini dibandingkan ibu yang bukan partus lama. Probabilitas ibu dengan partus lama yang mengalami perdarahan postpartum dini yaitu $72 \%$, sedangkan probabilitas ibu yang bukan partus lama yang mengalami perdarahan postpartum dini yaitu $34,29 \%$. Dengan demikian diperoleh rasio prevalensi sebesar 2,1 yang menunjukkan bahwa partus lama merupakan faktor risiko terjadinya perdarahan postpartum dini.

Terdapat hubungan yang signifikan secara statistik antara partus lama dengan kejadian perdarahan post partum dini. Hal ini didapatkan melalui perbandingan chi square hitung dengan chi square tabel dan signifikansi dengan alpha 0,01 yaitu didapatkan bahwa chi square hitung yaitu 8,287 > chi square tabel yaitu 6,64 dan signifikansi yaitu 0,004 < alpha 0,01.

Koefisien kontingensi yang benilai positif menunjukkan hubungan yang searah yaitu semakin lama persalinan maka ibu akan cenderung mengalami perdarahan post partum dini. Besarnya hubungan antara partus lama dengan kejadian perdarahan 
postpartum dini adalah 0,349. Hasil tersebut menunjukkan bahwa pengaruh partus lama dengan kejadian perdarahan postpartum dini termasuk rendah yaitu sebesar $12,18 \%$. Sementara pengaruh faktor lain terhadap kejadian perdarahan postpartum dini adalah sebesar $87,82 \%$.

\section{Pembahasan}

\section{Partus Lama}

Dari hasil penelitian didapatkan sebanyak 25 ibu mengalami partus lama. Partus lama ditandai dengan partograf yang melewati garis waspada pada kala I fase aktif dan lama kala II melebihi 2 jam pada primipara dan melebihi 1 jam pada multipara. Ibu yang mengalami fase aktif memanjang sebanyak 19 ibu dan ibu yang mengalami kala II memanjang sebanyak 6 ibu. lbu yang mengalami fase aktif memanjang terdiri dari 3 ibu primipara dan 16 ibu multipara, sedangkan ibu yang mengalami kala II memanjang terdiri dari 4 ibu primipara dan 2 ibu multipara.

Pada ibu primipara, ketiga faktor persalinan yaitu power, passage dan passanger belum teruji. Dengan demikian, pada primipara proses persalinan kala II berlangsung lebih lama dibandingkan multipara. Selain itu, pada primipara otot-otot jalan lahir masih kaku dan belum dapat mengejan dengan baik, sedangkan pada multipara proses persalinan pada kala II akan terjadi lebih cepat karena adanya pengalaman persalinan yang lalu dan disebabkan otot-otot jalan lahir yang lebih lemas.

His yang tidak normal dalam kekuatan dan sifatnya menyebabkan rintangan pada jalan lahir yang lazim terdapat pada setiap persalinan dan tidak dapat diatasi sehingga persalinan mengalami hambatan atau kemacetan. ${ }^{2}$ Pada fase aktif memanjang, kontraksi melemah sehingga menjadi kurang kuat, lebih singkat dan atau lebih jarang, kualitas kontraksi sama seperti semula, tidak mengalami kemajuan sehingga pada pemeriksaan vaginal, serviks tidak mengalami perubahan. Pada kala II memanjang, pembukaan serviks telah lengkap tetapi proses lahirnya janin terhambat. Hal tersebut dapat disebabkan oleh his yang tidak adekuat, kelainan panggul, kelainan letak janin, pimpinan persalinan yang salah, janin besar atau kelainan kongenital serta ketuban pecah dini.

Partus lama baik fase aktif memanjang maupun kala II memanjang menimbulkan efek terhadap ibu maupun janin. Terdapat kenaikan terhadap insidensi atonia uteri, laserasi perdarahan, infeksi, kelelahan ibu dan syok. Angka kelahiran dengan tindakan yang tinggi semakin memperburuk bahaya bagi ibu. ${ }^{5}$

Pada partus lama, ibu mengalami kelelahan karena tanpa makan dan minum yang dapat menyebabkan terjadinya dehidrasi, tampak sakit, pucat, mata cekung, dan berkeringat dingin, nadi meningkat, tensi turun dan temperatur meningkat, his mulai melemah dan perut tampak kembung. Selain itu, pada partus lama kerja sama 3P tidak sempurna sehingga terjadi kemacetan penurunan. ${ }^{6}$

\section{Kejadian Perdarahan Postpartum Dini}

Kejadian perdarahan postpartum dini dibedakan menjadi dua kategori yaitu perdarahan postpartum dini dan bukan perdarahan postpartum dini. Pada penelitian ini, ibu yang mengalami kejadian perdarahan postpartum dan ibu yang tidak mengalami kejadian perdarahan postpartum dini ditemukan sebanding yaitu masing-masing sebanyak 30 orang

Berdasarkan data yang diperoleh selama penelitian dapat diketahui bahwa penyebab terbanyak dari perdarahan postpartum dini adalah atonia uteri. Dalam persalinan pembuluh darah yang ada di uterus melebar yang meningkatkan sirkulasi ke arah tersebut, atonia uteri menyebabkan kontraksi uterus menurun sehingga pembuluh darah yang melebar tadi tidak menutup sempurna sehingga perdarahan terjadi terus menerus. 
Gejala yang selalu ada pada atonia uteri adalah uterus tidak berkontraksi dan lembek serta perdarahan segera setelah anak lahir. ${ }^{7}$

Atonia uteri merupakan penyebab utama dalam kasus perdarahan postpartum dini. Keadaan ini berhubungan erat dengan kondisi uterus yang sudah menurun sehingga kontraksi uterus jelek dan tidak bisa mengantisipasi terjadinya perdarahan postpartum dini. Itulah sebabnya atonia uteri lebih banyak terjadi pada seorang wanita dengan partus lama sehingga rentan terjadi perdarahan postpartum. Tetapi sebaliknya, jika kontrol perdarahan dari tempat plasenta atau uterus dicapai dengan kontraksi yang lama dan retraksi serat miometrium yang saling memilin serta uterus yang kuat dan berkontraksi dengan baik maka tidak akan terjadi perdarahan postpartum. ${ }^{8}$

\section{Hubungan Partus Lama dengan Kejadian Perdarahan Postpartum Dini}

Pada penelitian ini, ibu yang mengalami lama persalinan dengan kategori partus lama lebih banyak mengalami kejadian perdarahan post partum dini dibandingkan yang bukan partus lama. Probabilitas ibu dengan partus lama yang mengalami perdarahan postpartum dini yaitu $72 \%$, sedangkan probabilitas ibu yang bukan partus lama yang mengalami perdarahan postpartum dini yaitu $34,29 \%$. Dengan demikian diperoleh rasio prevalensi sebesar 2,1, yang menunjukkan bahwa partus lama merupakan faktor risiko terjadinya perdarahan postpartum dini.

Berdasarkan hasil uji chi square dapat diketahui bahwa terdapat hubungan yang signifikan secara statistik antara partus lama dengan kejadian perdarahan post partum dini. Hal ini didapatkan melalui perbandingan chi square hitung dengan chi square tabel dan signifikansi dengan alpha 0,01 yaitu didapatkan bahwa chi square hitung yaitu $8,287>$ chi square tabel yaitu 6,64 dan signifikansi yaitu $0,004<$ alpha 0,01 sehingga hubungan tersebut terbukti signifikan secara statistik. Ibu dengan partus lama mempunyai resiko lebih besar untuk mengalami perdarahan postpartum dini.

Setelah bayi dilahirkan, uterus secara spontan berkontraksi. Kontraksi dan retraksi otot-otot uterus menyelesaikan proses ini pada akhir persalinan. Sesudah berkontraksi, sel miometrium tidak relaksasi, melainkan menjadi lebih pendek dan lebih tebal. Dengan kontraksi yang berlangsung kontinyu, miometrium menebal secara progresif, dan kavum uteri mengecil sehingga ukuran juga mengecil. Pada partus lama, ibu yang bersalin akan kelelahan. Hal tersebut akan mempengaruhi kontraksi uterus. Adanya gangguan retraksi dan kontraksi otot uterus akan menghambat proses pelepasan dan pengeluaran plasenta sehingga dapat terjadi retensio plasenta. Apabila terjadi retensio plasenta maka terjadi pula perdarahan yang banyak karena uterus tidak dapat berkontraksi dan beretraksi dengan baik.

Selain itu, kelelahan akibat partus lama juga dapat menyebabkan uterus benar-benar kehilangan tonus otot karena miometrium gagal berkontraksi dan beretraksi saat atau setelah plasenta lepas. Dalam kondisi normal, pelepasan plasenta selalu diikuti dengan perdarahan karena sinus-sinus maternalis ditempat insersinya pada dinding uterus terbuka. Biasanya perdarahan itu tidak banyak, sebab kontraksi dan retraksi otot-otot uterus menekan pembuluh-pembuluh darah yang terbuka sehingga lumennya tertutup. Kemudian pembuluh darah tersumbat oleh bekuan darah. Apabila uterus tidak berkontaksi dan beretraksi maka akan menghambat penutupan pembuluh darah yang terbuka ketika pelepasan plasenta dan menyebabkan perdarahan yang banyak. Keadaan demikian menjadi faktor utama penyebab perdarahan postpartum dini. Oleh karena itu semakin lama proses persalinan maka kemungkinan untuk terjadinya perdarahan postpartum dini semakin besar.

\section{Kesimpulan}

Pada periode 11 Juni - 11 September 2012 di kamar bersalin Rumah Sakit Umum dr. Saiful Anwar Malang diperoleh probabilitas ibu dengan partus lama yang mengalami perdarahan postpartum dini yaitu $72 \%$ dengan jumlah kejadian perdarahan postpartum dini adalah 30 kasus. 
Semakin lama proses persalinan maka kemungkinan untuk terjadinya perdarahan postpartum dini semakin besar.

\section{Saran}

1. Sejak ibu hamil disarankan melakukan antenatal care yang rutin, serta pemberian informasi tentang terjadinya partus lama dan perdarahan postpartum dini dan memperhatikan faktor-faktor predisposisi dari partus lama dan perdarahan postpartum dini serta melakukan pertolongan persalinan dengan baik.

2. Diharapkan pada penelitian selanjutnya dibahas lebih mendalam mengenai faktor-faktor lain yang meningkatkan resiko terjadinya perdarahan postpartum dini misalnya: jarak kehamilan yang pendek, berat badan bayi yang dilahirkan dan tentunya dengan jumlah responden yang lebih besar sehingga hasil uji lebih akurat.

\section{Daftar Pustaka}

1. Prawirohardjo S. Ilmu Kebidanan. Jakarta: Yayasan Bina Pustaka Sarwono Prawirohardjo. 2007.

2. Wahyuningsih. Insidensi Partus Lama pada Primipara dan Multipara di RSUD Dr. Moewardi Surakarta Tahun 2009. Skripsi. Surakarta: Fakultas Kedokteran Universitas Muhammadiyah Surakarta. 2010.

3. Wiludjeng R. Gambaran Penyebab Kematian. Rianto B (Editor). Cermin Dunia Kedokteran. 2007.

4. Jensen, Bobak, Lawdermilk. Keperawatan Maternitas. Wijayariani M (Penerjemah). Jakarta: EGC. 2004.

5. Oxorn H, Forte WR. Ilmu Kebidanan Patologi dan Fisiologi Persalinan. Mohammad, H (Penerjemah). Yogyakarta: Andi Offset. 2010.

6. Manuaba IAC, Manuaba IBGF, Manuaba IBG. Kapita Selekta Penatalaksanaan Rutin Obstetri Ginekologi dan KB. Jakarta: EGC. 2001. 7. Boyle M. Buku Saku Bidan. Meiliya E (Penerjemah). Jakarta: EGC. 2008.

8. Williams L. Wilkins. Active Versus Expectant Management of the Third Stage of Labor and Implementation of a Protocol. Journal of Perinat Neonat Nurs. 2010; 24(3):215-228. 